\title{
FREQUENCY OF GLAUCOMA IN CHILDREN WITH VERNAL CONJUNCTIVITIS USING STEROIDS
}

\author{
Sameen Afzal Junejo, Nazir Ashraf Laghari and Abdul Ahad Qazi
}

\begin{abstract}
OBJECTIVE: To determine the frequency of glaucoma in children with vernal conjunctivitis using topical steroids, referred to a tertiary eye care centre.

DESIGN: Descriptive case series.

SETTING: This study was carried out at department of Ophthalmology, Liaquat University Eye Hospital Hyderabad, Sindh - Pakistan, from July 2002 to December 2004 (Thirty months).

PATIENTS AND METHODS: A total of 200 patients with chronic allergic conjunctivitis using topical steroids (Betamethasone, Dexamethasone, Prednisolone) for more than six months were examined. A thorough examination including visual acuity, Goldmann applanation tonometry, Schiot'z tonometry, Gonioscopy, slit lamp examination and dilated Ophthalmoscopy were performed.

RESULTS: Out of 200 patients examined, fifteen (7.5\%) were found having raised intraocular pressure (secondary glaucoma) due to prolonged use of topical steroids. The rise of intraocular pressure was bilateral in three patients (1.5\%), and unilateral in twelve patients (6.0\%). The topical steroids were discontinued. One patient with vernal conjunctivitis using topical steroids since more than two years developed left optic disc pallor with constriction of visual field, and posterior sub capsular cataract. The intraocular pressure was not controlled by ocular hypotensive agents, and glaucoma filtration surgery was advised.

CONCLUSION: This study identifies the risk of intraocular pressure elevation in patients with allergic conjunctivitis, using topical steroids for longer periods. Long term use of topical and systemic steroids produces secondary open angle glaucoma similar to chronic simple glaucoma. We can conclude that Dexamethasone and Prednisolone are possible risk factors for producing glaucoma.
\end{abstract}

KEY WORDS: Vernal conjunctivitis. Corticosteroids. Glaucoma.

\section{INTRODUCTION}

Vernal conjunctivitis (Spring Catarrh) is a recurrent, bilateral, external ocular inflammation affecting children and young adults. It is an allergic disorder in which IgE-mediated mechanism is involved. Conjunctival eosinophils play important role in the histology of vernal Keratoconjunctivitis. ${ }^{1}$ The clinical features include recurrent bilateral ocular itching, conjunctival congestion, conjunctival oedema and lid oedema. Topical steroids are used as the first line treatment for ocular allergies since $1940 .^{2}$ The topical steroids used for prolonged periods can result into rise of intraocular pressure more than $23 \mathrm{mmHg}$, and precipitate an attack of glaucoma. ${ }^{3,4}$ It is not necessary that all patients using steroids will develop elevated intraocular pressure. ${ }^{5}$ The patients using steroids by topical or periocular route are more prone to develop glaucoma than using systemically. ${ }^{5}$ The steroids related increase in intraocular pressure (IOP) is due to increased out flow resistance induced by biochemical and morphological changes in trabecular mesh work cells. ${ }^{6}$ The cell changes may be in the trabecular mesh work size, the extra cellular matrix, the cyto-skeleton, cell adhesion as well as cell function. ${ }^{6}$ Myocilin, a glycoprotein (TIGR protein) secreted from trabecular meshwork cells, which circulates in the aqueous humor, has also been made responsible for steroid induced glaucoma and primary open angle glaucoma. ${ }^{7,8}$ According to another theory, prolonged use of topical steroids for several weeks can significantly inhibit phagocytic activity at the level of trabecular mesh work, leading to the accumulation of extra cellular debris, thus resulting into steroid-induced ocular hypertension. ${ }^{9}$ Other ocular side effects due to prolonged use of topical steroids include mydriasis, ptosis, inhibition of corneal epithelial or stromal healing, formation of cataracts, punctate staining, corneal-scleral melting, damage to the optic nerve and defects in visual acuity and visual fields. ${ }^{10,11}$ 


\section{PATIENTS AND METHODS}

This study was conducted from July 2002 to December 2004 (Thirty months), at Liaquat University Eye Hospital Hyderabad, Sindh - Pakistan. A total of 200 patients with chronic allergic conjunctivitis, using topical steroids more than six months (Dexamethasone $0.1 \%$, Betamethasone, and Prednisolone acetate) were examined.

Inclusion Criteria: Patients within 12 years of age, having no personal or family history of pre existing glaucoma, connective tissue disease, high myopia, and diabetes mellitus.

Exclusion Criteria: Patients above 12 years, with corneal Krukenberg, KPs, hetero chromic irides, personal or family history of pre-existing glaucoma, history of ocular trauma and pigment dispersion.

Informed consent was obtained from the patients and/ or their parents. Complete ophthalmic examination was carried out, including determination of visual acuity, slit lamp examination, Schiot'z tonometry, and applanation tonometry. The applanation tonometry was done on patients above eight years of age. While in patients below eight years, due to their noncooperation, the intraocular pressure was checked by Schiot'z tonometer and Perkin's hand held tonometer, with and without general anesthesia. Perimetry by confrontation and arc methods was performed on patients more than eight years of age. The dilated Ophthalmoscopy was performed on all patients with and without general anesthesia. Automated computerized field analysis generally could not be done because of poor socio economic condition of patients. During this study period, the facilities for automated perimetry were not available in this set up. The examination of angle of anterior chamber (gonioscopy) was done by Goldmann three mirror contact lens on patients above eight years.

\section{RESULTS}

A total of two hundred patients up to the age of 12 years, suffering from chronic vernal conjunctivitis were screened. Age and sex distribution of patients is presented in Table I. All of the affected children were using topical steroids. The clinical ocular findings in all affected children on first visit are summarized in Table II. Out of 200 patients, only fifteen (7.5\%) were diagnosed having raised intraocular pressure more than
$23 \mathrm{mmHg}$. Age and sex distribution of these patients is mentioned in Table III. All the fifteen affected patients were already on treatment of topical steroids (Dexamethasone $0.1 \%$ and Prednisolone acetate). The duration of treatment with the state of intraocular pressure and overall visual acuity (with and without correction) on their first visit to Liaquat University Eye hospital is mentioned in Table IV. The topical steroids to all those patients diagnosed as secondary glaucoma were discontinued, and replaced by mast cell stabilizers and non-steroidal anti-inflammatory medications (topical eye drops). Out of fifteen, four patients were lost to follow up, while remaining eleven fulfilled the follow up criteria of this study which included regular visits to the hospital for examination and intra ocular pressure assessment during treatment. Within three to six weeks of discontinuation of topical steroids, ten out of eleven patients showed a positive response and the intraocular pressure reduced to normal levels i.e. $<20 \mathrm{mmHg}$. The overall visual acuity with and without correction is mentioned in Table V. On dilated Ophthalmoscopy, there was no sign of glaucomatous optic disc damage in ten out of eleven patients. One boy of five years age had visual acuity; right eye 6/24 and left eye 6/60 (corrected) with afferent pupillary defect in left eye. Even after discontinuation of topical steroids, the intraocular pressure was $20 \mathrm{mmHg}$ right eye and $28 \mathrm{mmHg}$ left eye. The left eye showed marked deterioration of visual fields. The patient had also developed posterior sub capsular lenticular changes in left eye. The ocular hypotensive agents i.e. topical beta blockers $0.5 \%$ and topical carbonic anhydrase inhibitors, were prescribed to the patients twice a day and counseling to the parents was done for left eye glaucoma filtration operation.

TABLE I:

AGE AND SEX DISTRIBUTION OF CASES $(n=200)$

\begin{tabular}{|l|c|c|c|}
\hline Age in Years & Sex & No. of Patients & Percentage \\
\hline 2 to 4 & M & 35 & $17.5 \%$ \\
& F & 21 & $10.5 \%$ \\
\hline 5 to 7 & M & 57 & $28.5 \%$ \\
& F & 33 & $16.5 \%$ \\
\hline 8 to 10 & M & 24 & $12.0 \%$ \\
& F & 12 & $06.0 \%$ \\
\hline \multirow{2}{*}{11 to 12} & M & 13 & $06.5 \%$ \\
& F & 05 & $02.5 \%$ \\
\hline
\end{tabular}


TABLE II:

CLINICAL OCULAR FINDINGS ON FIRST VISIT TO EYE HOSPITAL $(n=200)$

\begin{tabular}{|l|c|c|}
\hline \multicolumn{1}{|c|}{ Ocular Findings } & No. of Patients & Percentage \\
\hline $\begin{array}{l}\text { Conjunctival chemo- } \\
\text { sis, papillae, Mucus } \\
\text { discharge }\end{array}$ & 160 & $80 \%$ \\
\hline $\begin{array}{l}\text { Cobble stone papil- } \\
\text { lae, Trantas dots }\end{array}$ & 33 & $16.5 \%$ \\
\hline $\begin{array}{l}\text { Giant papillae, trantas } \\
\text { dots with corneal } \\
\text { plaque/shield corneal } \\
\text { ulcer }\end{array}$ & 06 & $03 \%$ \\
\hline $\begin{array}{l}\text { Conjunctival papillae, } \\
\text { chemosis, Post.sub- } \\
\text { capsular cataract, } \\
\text { Optic disc pallor }\end{array}$ & 01 & $0.5 \%$ \\
\hline
\end{tabular}

TABLE III:

AGE AND SEX DISTRIBUTION OF CHILDREN HAVING GLAUCOMA $(n=15)$

\begin{tabular}{|l|l|c|c|}
\hline Age in Years & Sex & No. of Patients & Percentage \\
\hline 2 to 4 & M & 02 & $13.6 \%$ \\
& F & 01 & $06.6 \%$ \\
\hline 5 to 7 & M & 01 & $06.6 \%$ \\
& F & 01 & $06.6 \%$ \\
\hline 8 to 10 & M & 04 & $26.6 \%$ \\
& F & 02 & $13.6 \%$ \\
\hline 11 to 12 & M & 03 & $19.8 \%$ \\
& F & 01 & $06.6 \%$ \\
\hline
\end{tabular}

TABLE IV:

CLINICAL FINDINGS AMONG GLAUCOMA AFFECTED PATIENTS ON THEIR FIRST VISIT AT EYE HOSPITAL $(n=15)$

\begin{tabular}{|l|c|c|c|}
\hline $\begin{array}{c}\text { No. of Pa- } \\
\text { tients (\%) }\end{array}$ & $\begin{array}{c}\text { Duration of } \\
\text { Treatment }\end{array}$ & $\begin{array}{c}\text { IOP } \\
\mathbf{m m H g}\end{array}$ & Overall VIA \\
\hline $02(13.3 \%)$ & 1 year or so & 23 to 26 & Cards test +ve \\
\hline $04(26.6 \%)$ & $\begin{array}{c}6 \text { to } 12 \\
\text { Months }\end{array}$ & 24 to 28 & $6 / 18$ to $6 / 12$ \\
\hline $05(33.3 \%)$ & 1 to 2 Years & 26 to 30 & $6 / 36$ to $6 / 18$ \\
\hline $04(26.6 \%)$ & 2 to 4 Years & 28 to 32 & $6 / 60$ to $6 / 24$ \\
\hline
\end{tabular}

$\mathrm{IOP}=$ Intraocular Pressure, $\mathrm{V} / \mathrm{A}=$ Visual Acuity.
TABLE V:

INTRAOCULAR PRESSURE AFTER STEROIDS DISCONTINUATION ( $n=11)$

\begin{tabular}{|c|c|c|c|}
\hline $\begin{array}{c}\text { No. of } \\
\text { Patients } \\
\text { (\%) }\end{array}$ & $\begin{array}{c}\text { Duration of } \\
\text { Steroids Dis- } \\
\text { continuation }\end{array}$ & $\begin{array}{c}\text { IOP } \\
\text { mmHg }\end{array}$ & Overall VIA \\
\hline $06(54.5 \%)$ & 3 to 4 Weeks & 14 to 17 & $6 / 12$ to $6 / 9$ \\
\hline $04(36.3 \%)$ & 4 to 6 Weeks & 16 to 19 & $6 / 18$ to $6 / 9$ \\
\hline $01(9.2 \%)$ & upto 6 Weeks & 30 to 36 & $6 / 24$ to $6 / 60$ \\
\hline
\end{tabular}

\section{DISCUSSION}

Steroid induced glaucoma is defined as "An increase in intraocular pressure, greater than $23 \mathrm{mmHg}$ with topically applied or systemically induced steroids". ${ }^{12,13}$ There is no gender or racial concern to the steroid responsive elevation of intraocular pressure. ${ }^{13} \mathrm{Ap}$ proximately $5 \%$ of general population is considered to be the steroid responders. ${ }^{14,15}$ In this study, the frequency of steroid induced ocular hypertension was $7.5 \%$, slightly higher. It may be due to unawareness to the steroid induced complication, and vigorous use of topical steroids. Patients suffering from allergic conjunctivitis are frequently prescribed topical steroids by most of the general medical practitioners without routine monitoring of visual acuity, intraocular pressure, and fundus examination.

In this study, most of the patients suffering from vernal conjunctivitis were referred from different primary (rural) and secondary (district) health centers. The steroid induced ocular hypertension can occur in people of all ages. ${ }^{15}$ In this study, the registered patients with raised intraocular pressure were between two to twelve years of age. Steroid-induced intraocular pressure elevation rarely occurs within first two weeks of treatment. After this period, intraocular pressure starts rising any time from weeks to years. ${ }^{16,17}$ Withdrawal of the steroid usually results in lowering of IOP to normal levels within two to four weeks. ${ }^{18}$ In this study, ten out of eleven patients recovered from raised IOP after discontinuation of topical steroids, except one who had extended glaucoma damage and was advised for glaucoma filtration surgery. The predisposing factors for IOP elevation are patients having more than 40 years of age, diabetes mellitus, high myopia and pre-existing open-angle glaucoma. ${ }^{18,19}$ In this study, all those patients who were above twelve years, suffering from diabetes mellitus, high myopia and preexisting glaucoma were not included. Steroid induced ocular hypertension (the steroid response) is associated with the pathophysiology of primary open angle glaucoma. ${ }^{20}$ In this study, most of the patients whom the gonioscopy was performed had open angles. The 
steroid induced intraocular pressure elevation for prolonged time results in glaucomatous optic atrophy and visual loss even after discontinuation of steroids and the IOP returning to normal levels. ${ }^{20}$ In this study, one patient out of eleven, developed optic atrophy and posterior sub capsular lenticular changes. The incidence of IOP response is more frequent to the use of topical Dexamethasone, and less frequent with the Fluorometholones. ${ }^{21}$ In our study, all of the patients diagnosed as steroid induced glaucoma, were predominantly using topical Dexamethasone $0.1 \%$. Fluorometholone is considered superior for its avoidance of increased IOP and most side effects, and therefore is given priority for long term use in ocular inflammations. ${ }^{22}$ Non-steroidal anti inflammatory drugs (NSAIDs) have been considered better replacement to topical steroids due to their negligible side effects. ${ }^{23,24}$ NSAIDs are useful in controlling pain and inflammation without reducing the immune system. These drugs block only cyclo-oxygenase pathways and therefore inhibit the formation of prostaglandins and the subsequent products in this metabolic pathway. ${ }^{25}$ Use of inhaled steroids in children suffering from allergic asthma have emerged as another important source of causing secondary open angle glaucoma. $^{26,27}$

\section{CONCLUSION}

This study is quite valuable for the reasons that, many patients who receive steroid therapy by topical or systemic routes for prolonged period, are susceptible to develop ocular hypertension, which if undiagnosed can lead to glaucomatous optic neuropathy and irreversible loss of vision. On discontinuation of steroids, the intraocular pressure returns to the normal levels without producing glaucoma damage. The topical or systemic steroids should be prescribed with great care to avoid such life threatening hazards.

\section{REFERENCES}

1. Abelson MB, Madiwale N, Weston JH. Conjunctival eosinophilus in allergic ocular disease. Arch Ophthalmol. 1983;101(4):555-6.

2. Halpern MT. A pharmaco-economic analysis of Rimexolone for the treatment of ophthalmic inflammatory conditions. The Am J Managed Care. 1998; 4:6:854-62.

3. Iqbal Z, Muhammad Z, Shakirullah, Bashir S, Khan MD. Comparative studies of Dexamethazone, Betamethazone, Fluoromethalone and Diclofenac Sodium on IOP of the rabbits. Pak J Ophthalmol. 2002;18(3):61-5.

4. Clark AF. Steroids, ocular hypertention and glaucoma. J Glaucoma. 1995;4:354-369.

5. Renfro L, Snow JS. Ocular effects of topical and systemic steroids. Dermatol Clin. 1992;10:3:50512.

6. Johnson DH, Gottanka J, Flugel C. Ultra structural changes in the trabecular mesh work of human eyes treated with glucocorticoids. Arch Ophthalmol.1997; 115:375-383.

7. Suta GL, Morgan RK. Corticosteroid induced glaucoma. In: Rich R, Sheilds MB, Krupin T, eds. The Glaucomas. 2nd Edition. St Louis, CV Mosby,1996: Pp.1177-86.

8. Lutjen-Drecoll E, May CA, Polansky JR, Johnson $\mathrm{DH}$, Bloementhal $\mathrm{H}$, Nguyen TD. Localization of the stress proteins aB-crystallin and trabecular meshwork inducible glucocorticoid response protein in normal and glaucomatous trabecular meshwork. Invest Ophthalmol Vis Sci. 1998; 39: 517525.

9. Wordinger RJ and Clark AF. Effects of glucocorticoids on the trabecular meshwork: towards a better understanding of glaucoma. Prog Ret Eye Res. 1999;18:629-667.

10. Thygesen $\mathrm{P}$, Hogan MJ, Kimura SJ. Cortisone and hydrocortisone in ocular infection. Trans Am Acad Ophthalmol. 1955; 57:64-85.

11. Royal Pharmaceutical Society of Great Britain and British Medical Association. British national formulary. London: Pharmaceutical Press,1992: p. 379.

12. Abbot F, Clark and Robert J. Steroid Glaucoma. Glaucoma World. 2001;22: 1-5.

13. Armaly MF. Effect of corticosteroids on intraocular pressure and fluid dynamics. Arch Ophthalmol.1963;70-82.

14. Lester R, Knowles S, Shear N. The risk of systemic corticosteroid use. Dermatol Clin. 1998;1627.

15. Ohji M, Kinoshita S, Ohmi E. Marked intraocular pressure response to instillation of corticosteroids in children. Am J Ophthalmol.1991;112-119.

16. Armaly MF. Statistical attributes of the steroid hypertension response in the clinically normal eye. I. The demonstration of three levels of response. Invest Ophthalmol Vis Sci. 1965; 4:187-97.

17. Leibowitz HM, Kupperman A. Uses of corticosteroids in the treatment of corneal inflammation. In: Leibowitz HM, ed. Corneal Disorders, Clinical Diagnosis and Management. Philadelphia: W.B. Saunders, 1984: Pp. 286-307.

18. Tripathi RC, Parapuram SK, Tripathi BJ. Corticosteroids and glaucoma risk. Drugs and Aging. 1999;15(6):439-450.

19. Carnahan MC, Goldstein DA. Ocular complications of topical, peri-ocular and systemic corticosteroids. Curr Opin Ophthalmol. 2000;11:478-483.

20. Polansky JR. Side effects of ophthalmic therapy with anti-inflammatory steroids. Curr Opin Oph- 
thalmol.1992;259-272.

21. Melton R, Thomas R. Corticosteroids. In: Melton R, Thomas R. 2001 Clinical Guide to Ophthalmic Drugs. Rev Optom Suppl. 2001;18A-21A.

22. Jampol LM. Pharmacologic therapy of aphakic cystoid macular edema: a review. Ophthalmology.1982; 89:891-897.

23. Flach AJ, Dolan BJ, Donahue ME. Comparative effects of Ketorolac $0.5 \%$ and Diclofenac $0.1 \%$ ophthalmic solutions on inflammation after cataract surgery. Ophthalmology.1991;105:1775-9.

24. Flach AJ. Non-steroidal anti-inflammatory drugs.
In: Tasman W, ed. Duane's Foundations of Clinical Ophthalmology. Philadelphia: Lippincott, 1994:132.

25. Flach AJ. Cyclo-oxygenase inhibitors in ophthalmology. Surv Ophthalmol. 1992; 36:259-284.

26. Garbe E, LeLorier J, Boivin J, Suissa S. Inhaled and nasal glucocorticoids and the risks of ocular hypertension or open angle glaucoma. JAMA. 1997;277:722-7.

27. Stanbury R, Graham E. Systemic steroid therapy, side effects and their management. $\mathrm{Br} \mathrm{J} \mathrm{Oph-}$ thalmol.1998; 70-82.

\begin{tabular}{|l|}
\multicolumn{1}{|c|}{ AUTHOR AFFILIATION: } \\
Dr. Sameen Afzal Junejo (Corresponding Author) \\
Assistant Professor \\
Liaquat University Eye Hospital \\
Hyderabad, Sindh - Pakistan. \\
Email:Sameenafzal1@yahoo.com \\
Prof. Nazir Ashraf Laghari \\
Department of Ophthalmology \\
Isra University Hospital \\
Hyderabad - Sindh. \\
Dr. Abdul Ahad Qazi \\
Consultant Ophthalmologist \\
Isra University Hospital \\
Hyderabad - Sindh.
\end{tabular}

